\title{
Zastosowanie wybranych bodźców fizykalnych podczas profesjonalnych zabiegów kosmetologicznych. Część II. Fale ultradźwiękowe
}

\section{The use of selected physical stimuli during professional cosmetology treatments. Part II. Ultrasonic waves}

\author{
Jolanta Wesołowska1 ${ }^{凶}$, Iza Iwan-Ziętek¹, Hanna Mosiejczuk², Ewa Kemicer-Chmielewska³, \\ Mariola Marchlewicz ${ }^{1}$ \\ ${ }^{1}$ Pomorski Uniwersytet Medyczny w Szczecinie, Zakład Dermatologii Estetycznej, al. Powstańców Wlkp. 72, 70-111 Szczecin \\ ${ }^{2}$ Pomorski Uniwersytet Medyczny w Szczecinie, Samodzielna Pracownia Rehabilitacji Medycznej, ul. Żołnierska 48, 71-210 Szczecin \\ ${ }^{3}$ Pomorski Uniwersytet Medyczny w Szczecinie, Katedra i Zakład Zdrowia Publicznego, ul. Żołnierska 48, 71-210 Szczecin \\ $\bowtie$ jolanta.wesolowska@pum.edu.pl
}

\section{ABSTRACT}

Ultrasonic waves are an integral part of almost every modern cosmetology treatment. They are used during cavitation peeling or sonophoresis to facilitate the absorption of active substances.
Ultrasound of specific frequencies induce a cavitation wave, which is used during anti-cellulite and body sculpting treatments. Keywords: ultrasonic waves; sonophoresis; cavitation peeling.

\begin{abstract}
ABSTRAKT
Ultradźwięki są we współczesnej kosmetologii nieodłącznym elementem prawie każdego zabiegu kosmetycznego. Wykorzystywane są podczas peelingu kawitacyjnego, sonoforezy ułatwiającej przenikanie substancji aktywnych. Ultradźwięki
\end{abstract}

o określonej częstotliwości drgań indukują falę kawitacyjną, co jest wykorzystywane podczas zabiegów antycellulitowych i modelowania sylwetki ciała.

Słowa kluczowe: ultradźwięki; sonoforeza; peeling kawitacyjny.
Ultradźwięki należą do rodzaju fal akustycznych generujących drgania ośrodka, w którym ma miejsce ich propagacja. Nowa „Encyklopedia Powszechna PWN” definiuje je jako „(...) fale sprężyste nie wywołujące wrażenia słuchowego, o częstotliwości w przedziale $16 \mathrm{kHz}-10 \mathrm{GHz}$ ". Ten zakres częstotliwości fali akustycznej nie wywołuje wrażenia słuchowego u ludzi, natomiast może być odbierany przez niektóre zwierzęta [1]. Specyficzne oddziaływanie ultradźwięków z materią, zarówno bierne, jak i czynne, pozwoliło na szerokie ich zastosowanie w różnych dziedzinach życia. Bierne oddziaływanie polegające na wytwarzaniu i detekcji fal ultradźwiękowych o niskim natężeniu znalazło zastosowanie w defektoskopii ultradźwiękowej, hydrolokacji oraz w diagnostyce medycznej. Zmiany struktury ośrodka (materii, ciała) analizowane są za pomocą oceny zmian parametrów pola akustycznego. Natomiast czynne oddziaływanie fal akustycznych w obrębie struktury ośrodka (materii) opiera się na zastosowaniu średniej i dużej mocy (natężenia) ultradźwięków, co wpływa na zmiany biologiczne, fizyczne i chemiczne w jego obrębie. W materii poddanej oddziaływaniu dużych sił dochodzi do powstania nieodwracalnych zmian makroskopowych pod wpływem procesu kawitacji i reakcji chemicznych, koagulacji i dyspergowania ultradźwiękowego.
Duże natężenie fal ultradźwiękowych wykorzystywane jest w przemyśle podczas obróbki plastycznej materiałów twardych i kruchych, oczyszczania materii, spajania metali (lutowania), a także w medycynie oraz kosmetologii.

We współczesnej medycynie ultrasonografia stała się rutynową i nieinwazyjną procedurą diagnostyczną, a zastosowanie ultradźwięków w celach terapeutycznych wpływa korzystnie na skuteczność leczenia [2,3]. Działanie terapeutyczne fal ultradźwiękowych oparte jest na zjawisku pochłaniania energii przez tkanki i przetwarzania jej w ciepło. Wytworzone ciepło zwiększa również energię kinetyczną białek, lipidów i węglowodanów będących składnikami błony komórkowej, co wpływa na stopień jej przepuszczalności. W wyniku oddziaływania pola ultradźwiękowego w układach biologicznych o różnej gęstości pojawiają się naprężenia w postaci sił pławnych (o charakterze oscylacyjnym), sił przemieszczania i sił związanych ze zmianą lepkości. Innym obserwowanym efektem biologicznym oddziaływania fal ultradźwiękowych jest zjawisko kawitacji, które polega na formowaniu w cieczy pęcherzyków próżniowych, pęcherzyków wypełnionych nasyconą parą lub gazem rozpuszczonym w cieczy. Do powstania zjawiska kawitacji dochodzi w wyniku przekroczenia określonego progu 
natężenia i częstotliwości fal ultradźwiękowych zależnych od rodzaju cieczy, zawartych w niej cząstek gazu oraz mikroskopijnych zanieczyszczeń (stanowiących podłoże powstawania pęcherzyków kawitacyjnych) [2]. Mechanizm kawitacji w tkankach występuje podczas stosowania ultradźwięków o częstotliwościach $3 \mathrm{MHz}$ i 0,75 MHz (i przy zastosowaniu fali ciągłej), o natężeniu 0,68 W/ $\mathrm{cm}^{2}$ i 0,5 W/ $/ \mathrm{cm}^{2}$ [4]. Podczas liposukcji chirurgicznej (inwazyjnej) stosowane jest natężenie ultradźwięków w granicach $19-21 \mathrm{~W} / \mathrm{cm}^{2}$ i $100 \%$ wypełnienie fali. W przypadku liposukcji niechirurgicznej (zewnętrznego oddziaływania ultradźwięków) efekt „lipokawitacji” występuje przy natężeniu $2,5 \mathrm{~W} / \mathrm{cm}^{2}$ i $100 \%$ wypełnieniu fali ultradźwiękowej [5].

Tkankami o wysokim współczynniku absorpcji ultradźwię ków są kości, ścięgna, tkanka nerwowa i mięśnie. Ultradźwięki o natężeniach $\mathrm{w}$ przedziale $2-3 \mathrm{~W} / \mathrm{cm}^{2}$ i częstotliwościach w granicach $800 \mathrm{kHz}$ powodują mikromasaż tkanek, wpływając na ich miejscowe przekrwienie oraz korzystne zmiany $\mathrm{w}$ funkcjonowaniu układu limfatycznego. W fizykoterapii oraz kosmetologii najczęściej stosowane są ultradźwięki o częstotliwości $750 \mathrm{kHz}-3 \mathrm{MHz}$ oraz natężeniu 0,5-2,0 W/ $\mathrm{cm}^{2}$. Czas trwania zabiegu uzależniony jest od natężenia ultradźwięków [6].

Ze względu na fakt, iż ten rodzaj fal jest bodźcem dla wielu zjawisk na poziomie komórek i tkanek, wpływającym na poprawę metabolizmu i przyspieszenie procesów gojenia, znalazł zastosowanie podczas nieinwazyjnych zabiegów kosmetycznych, tzw. peelingu kawitacyjnego, sonoforezy, zabiegu liposukcji (niechirurgicznej), modelowania sylwetki, liftingu ultradźwiękowego oraz zabiegów antycellulitowych [7, 8, 9]. Zabiegi z zakresu dermatologii estetycznej i kosmetologii zazwyczaj oparte są na oddziaływaniu fal ultradźwiękowych o częstotliwości $22 \mathrm{kHz}-5 \mathrm{MHz}$ i natężeniu o maksymalnej wartości do 2-3 W/cm². Ultradźwięki o niższej częstotliwości oddziałują na głębsze warstwy skóry, natomiast niższe częstotliwości intensywniej oddziałują na warstwy powierzchowne skóry. Jednak efekt zabiegu uzależniony jest od wielu czynników.

Bardzo istotna jest technika prowadzenia głowicy zabiegowej - metodą statyczną lub dynamiczną. Pierwsza technika polega na aplikacji ultradźwięków bez poruszania głowicą, jednak współcześnie metoda ta nie jest już stosowana ze względu na możliwość wystąpienia uszkodzeń tkanek powierzchownych (np. przy nieodpowiednio dobranych parametrach zabiegu). Aplikacja dynamiczna polega na wykonywaniu ruchów posuwistych lub spiralnych na powierzchni skóry w tempie 1 ruch na 2-4 s $[10,11,12]$.

Istotny wpływ na przebieg i efekt zabiegu mają również czas trwania zabiegu, który nie powinien być krótszy niż 5 min i trwać maksymalnie $15 \mathrm{~min}$, zastosowana częstotliwość i rodzaj fali, współczynnik wypełnienia fali, dawka natężenia ultradźwięków, powierzchnia przetwornika, powierzchnia i wrażliwość tkanek poddawanych zabiegowi oraz zastosowanie żelu przewodzącego - zawierającego odpowiednie polimery sprzęgające fale ultradźwiękowe (np. Żelpol, Coel). Przeciwwskazaniami do stosowania ultradźwięków są ciąża, wiek poniżej 18 lat, epilepsja, zaburzenia układu sercowo-naczyniowego, rozrusznik serca i inne elektroniczne implanty, stosowanie pompy infuzyjnej, niewyrównana cukrzyca, obecne w polu zabiegu implanty metalowe i zaburzenia czucia, wyniszczenie organizmu, infekcje wirusowe, grzybicze i bakteryjne w miejscu zabiegu, przerwanie ciągłości skóry, zaawansowana osteoporoza, bardzo liczne teleangiektazje, zakrzepowe zapalenie żył w miejscu zabiegu oraz w przypadku twarzy, np. stan po ekstrakcji zęba $[11,12,13]$.

Popularnym zabiegiem stosowanym we współczesnej kosmetologii stał się peeling ultradźwiękowy zwany kawitacyjnym. Podczas zabiegu używana jest specjalna głowica nazywana szpatułą kawitacyjną, która podobnie jak inne głowice emitujące ultradźwięki zawiera przetworniki piezoelektryczne odkształcające się pod wpływem pola elektromagnetycznego, wytwarzając fale ultradźwiękowe. W przypadku peelingu ultradźwiękowego nie można powołać się na badania potwierdzające występowanie zjawiska kawitacji podczas zabiegu kosmetycznego stosowanego na powierzchni skóry. Częstotliwość ultradźwięków generowana w urządzeniach kosmetycznych przeznaczonych do peelingu kawitacyjnego mieści się w przedziale 0,25-0,35 MHz. Podobnie ich natężenie nie jest wystarczające do wygenerowania wzrostu ciśnienia mogącego wpłynąć na zniszczenie struktur tkankowych. Podczas pracy szpatuły kawitacyjnej skórę należy ciągle zwilżać płynem (wodą mineralną niegazowaną, solą fizjologiczną, tonikiem bezalkoholowym lub przegotowaną wodą). Jednocześnie głowica powinna być delikatnie przesuwana po powierzchni skóry, czego efektem jest rozpylenie płynu. Drgania przenoszone na skórę ułatwiają usuwanie z jej powierzchni zanieczyszczeń wraz z nadmiarem łoju, zewnętrzną warstwą korneocytów i resztkami kosmetyków, natomiast nie należy szpatułą kawitacyjną usuwać („wyciskać") zaskórników. Podczas profesjonalnej pielęgnacji zabieg ten przygotowuje skórę do aplikacji składników aktywnych zawartych w kosmetykach. Dodatkowo mikromasaż wpływa stymulująco na mikrokrążenie, co usprawnia procesy metaboliczne w skórze. Bezpośrednio po zabiegu skóra jest gładka w dotyku oraz lekko rozjaśniona, sprawiając wrażenie „odświeżonej”. Poprawnie przeprowadzony zabieg nie powoduje powikłań i może być stosowany w przypadku każdego rodzaju cery (również wrażliwej i naczyniowej), z uwzględnieniem ogólnych przeciwwskazań do zastosowania ultradźwięków [12, 13, 14].

Kolejnym rodzajem zabiegu kosmetycznego z wykorzystaniem ultradźwięków jest sonoforeza. Podczas tego zabiegu fale ultradźwiękowe usprawniają transport substancji aktywnych do skóry. Badania dotyczące wpływu ultradźwięków na błony plazmatyczne erytrocytów wykazały zmiany czynnościowe polegające m.in. na zwiększeniu ich przepuszczalności [2]. Fala ultradźwiękowa oprócz wpływu na zmianę potencjału spoczynkowego błon komórkowych może również powodować zwiększenie energii kinetycznej cząsteczek preparatu kosmetycznego stosowanego podczas zabiegu. Miejscowe oddziaływanie ultradźwięków na tkanki wpływa na poprawę ukrwienia i tym samym stwarza korzystniejsze warunki do absorpcji składników aktywnych zawartych w kosmetykach przeznaczonych do sonoforezy. Preparaty kosmetyczne stosowane podczas 
zabiegu powinny być odpowiednio przygotowane przez firmę kosmetyczną. Podczas sonoforezy stosowane są różne formy preparatów kosmetycznych (żele, kremy lub emulsje), które powinny charakteryzować się większym uwodnieniem oraz zawierać odpowiednie stężenie substancji aktywnych w celu osiągnięcia zamierzonego efektu zabiegu. W przypadku serum kosmetycznego, które nie ma formuły nadającej się do sonoforezy, można zastosować połączenie tego preparatu ze środkiem sprzęgającym lub nanieść serum bezpośrednio na skórę, a następnie żel (z odpowiednim polimerem) poprawiający właściwości sprzęgające stosowanego kosmetyku [14, 15]. Efektywność zabiegu sonoforezy jest również zależna od stanu skóry i odpowiedniego jej przygotowania przed zabiegiem (wykonania peelingu). W zależności od użytego preparatu kosmetycznego (rodzaju substancji aktywnych) sonoforezę można stosować podczas zabiegów pielęgnacyjnych w przypadku każdego rodzaju cery, zabiegów wspomagających leczenie trądziku różowatego, trądziku pospolitego, podczas zabiegów przeciwstarzeniowych i liftingujących oraz zabiegów antycellulitowych i modelujących sylwetkę, z uwzględnieniem ogólnych przeciwwskazań do zastosowania ultradźwięków oraz przeciwwskazań dotyczących reakcji alergicznych na preparaty stosowane podczas zabiegu. Efekt uzyskany po zabiegach sonoforezy jest wypadkową oddziaływania na tkanki fal ultradźwiękowych oraz substancji wprowadzanych do skóry za ich pośrednictwem $[9,15,16]$. W tabelach 1 i 2 przedstawiono wybrane preparaty przeznaczone do sonoforezy. W tabeli 3 przedstawiono wybrane urządzenia kosmetyczne stosowane podczas profesjonalnych zabiegów.

Obecnie bardzo popularne stały się zabiegi wpływające na zmniejszenie grubości tkanki tłuszczowej, zabiegi antycellulitowe czy tzw. modelujące sylwetkę, podczas których

TABELA 1. Preparaty kosmetyczne przeznaczone do zabiegów pielęgnacyjnych z zastosowaniem ultradźwięków w obrębie skóry twarzy (na podstawie materiałów informacyjnych producenta dołączonych do produktów kosmetycznych)

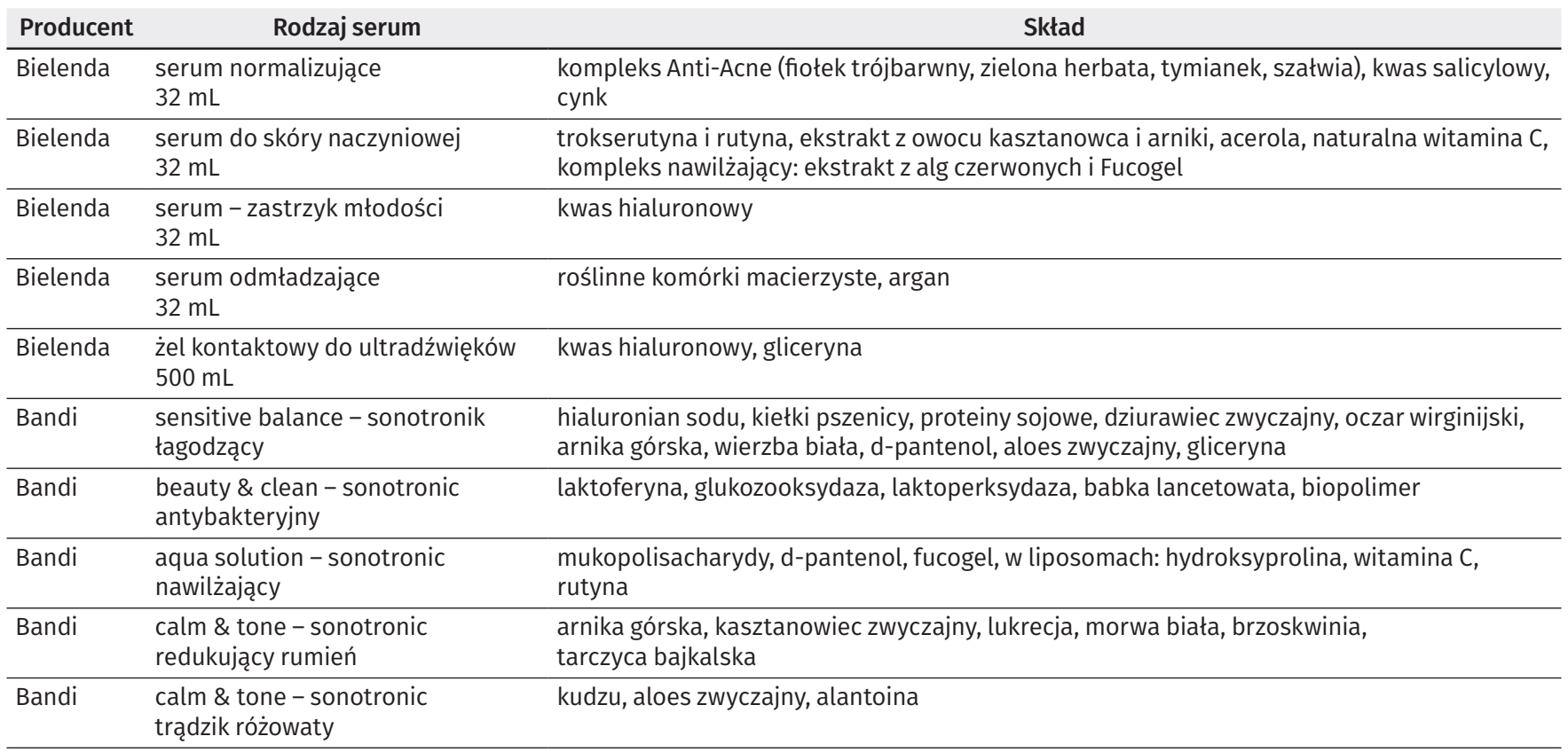

TABELA 2. Preparaty kosmetyczne stosowane podczas zabiegów antycellulitowych wpływających na modelowanie sylwetki ciała, nawilżających i regenerujących skórę (na podstawie materiałów informacyjnych producenta dołączonych do produktów kosmetycznych)

\begin{tabular}{lll} 
Producent & \multicolumn{1}{c}{ Serum } & \multicolumn{1}{c}{ Skład } \\
\hline Biomak & $\begin{array}{l}\text { żel drenująco-antycellulitowy } \\
150 \mathrm{~mL}\end{array}$ & ekstrakt guarany z kofeiną, traganek chiński, ruszczyk, nawłoć \\
\hline Biomak & $\begin{array}{l}\text { żel wyszczuplający } \\
150 \mathrm{~mL}\end{array}$ & ekstrakt guarany z kofeiną, algi, kasztanowiec, kiełki, ostropest plamisty \\
\hline Biomak & żel wyszczuplająco-antycellulitowy & algi, guarana z kofeiną, traganek, ruszczyk, cytryna, nawłoć \\
& $150 \mathrm{~mL}$ & mocznik, ekstrakt drzewa Tara, mleczan sodu, algi \\
\hline Biomak & żel nawilżająco-dotleniający & \\
\hline Biomak & $\begin{array}{l}\text { żel regenerująco-nawilżający } \\
150 \mathrm{~mL}\end{array}$ & $\begin{array}{l}\text { kompleks mineralny, kwas hialuronowy, ekstrakt z winorośli, ruszczyka i oczaru } \\
\text { wirginijskiego }\end{array}$ \\
\hline Norel & żel aktywny antycellulitowy & kofeina, L-karnityna, IsoNari, wyciąg z zielonej herbaty \\
\hline Norel & $250 \mathrm{~mL}$ & \\
\hline
\end{tabular}


wykorzystywane jest działanie ultradźwięków [17]. Na rynku medycyny estetycznej i kosmetologii dostępna jest bardzo obszerna oferta urządzeń przeznaczonych do wykonywania zabiegów „lipokawitacji” ultradźwiękowej, określanej również jako „liposukcja ultradźwiękowa” (tab. 4). Urządzenia posiadające certyfikat CE medyczny przeszły badania kliniczne pod kątem bezpieczeństwa i skuteczności, dając użytkownikowi gwarancję, iż parametry generowanych fal ultradźwiękowych osiągają wartości przekraczające „próg kawitacji”, indukując zmiany biologiczne w tkance tłuszczowej.

Oprócz wyboru odpowiedniego certyfikowanego urządzenia istotną rolę odgrywa właściwe przygotowanie tkanki tłuszczowej poprzez jej intensywne nawodnienie. Przed przystąpieniem do zabiegu „lipokawitacji” i w trakcie terapii konieczne jest zwiększenie ilości spożywanej wody mineralnej. W celu osiągnięcia korzystniejszego efektu oddziaływania ultradźwięków żel sprzęgający może być połączony z substancjami aktywnymi o właściwościach lipolitycznych [18, 19]. W celu wyeliminowania powikłań muszą być przestrzegane ogólne przeciwwskazania do stosowania ultradźwięków oraz omijane narządy miąższowe (nerki, wątroba, śledziona) i jajniki.

Zastosowanie ultradźwięków we współczesnej kosmetologii stało się powszechne, a umiejętne i bezpieczne wykorzystanie tego bodźca wpływa stymulująco na metabolizm skóry, ułatwia jej oczyszczanie, wspiera „walkę” z tkanką tłuszczową oraz ułatwia wprowadzanie składników aktywnych, wpływając korzystnie na efektywność profesjonalnych zabiegów kosmetycznych $[16,19]$.

\section{PIŚMIENNICTWO}

1. Śliwiński A. Ultradźwięki i ich zastosowanie. Warszawa: WNT; 2001.

2. Miłowska K. Ultradźwięki - mechanizmy działania i zastosowanie w terapii sonodynamicznej. Postepy Hig Med Dosw (online) 2007;61:338-49. www.phmd.pl/fulltxt.php?ICID=484896 (28.12.2016).

3. Bani D, Quattrinni Li A, Frechi G, Russo Lo G. Histological and ultrastructural effects of ultrasound-induced cavitation on human skin adipose tissue. Plast Reconst Surg Glob 2013;1(6):e41. doi: 10.1097/ GOX.0b013e3182a7f222. http://journals.lww.com/prsgo/Fulltext/2013/09000/Histological_and_Ultrastructural_Effects_of.7.aspx (6.01.2017).

4. Polak A, Dzikiewicz M, Taradaj J, Kucio C, Nawrot-Szołtysik A, Wiercigroch L, et al. Ocena wpływu ultradźwięków na proces gojenia odleżyn. Medsportpress 2012;4:363-78.

5. Palumbo P, Cinque B, Miconi G, la Torre C, Zoccali G, Vrentzos N, et al. Biological effect of low grequency high intensity ultrasound application on ex vivo human adipose tissue. Int J Immunopathol Pharmacol 2011;24(2):411-22.

TABELA 3. Urządzenia kosmetyczne przeznaczone do profesjonalnych zabiegów kosmetycznych (na podstawie materiałów informacyjnych producenta)

\begin{tabular}{|c|c|c|c|c|}
\hline $\begin{array}{l}\text { Rodzaj urządzenia } \\
\text { (producent) }\end{array}$ & Rodzaj głowicy i częstotliwość & Natężenie & Tryb pracy & CE \\
\hline $\begin{array}{l}\text { Peelign kawitacyjny G-195 } \\
\text { (Newface) }\end{array}$ & $\begin{array}{l}\text { szpatuła kawitacyjna } \\
28 \mathrm{kHz}\end{array}$ & & ciągły i impulsowy & tak \\
\hline $\begin{array}{l}\text { Peeling kawitacyjny LW006 } \\
\text { (Vanity_B) }\end{array}$ & $\begin{array}{l}\text { szpatuła kawitacyjna } \\
28 \mathrm{kHz}\end{array}$ & $7 \mathrm{~W}$ & 4 programy & - \\
\hline $\begin{array}{l}\text { Peeling kawitacyjny RE-H01 } \\
\text { (Royalelite) }\end{array}$ & $\begin{array}{l}\text { szpatuła kawitacyjna } \\
28 \mathrm{kHz}\end{array}$ & $\begin{array}{c}7 \mathrm{~W} \\
2 \mathrm{~W} / \mathrm{cm}^{2}\end{array}$ & $\begin{array}{l}\text { kawitacja, sonoforeza, } \\
\text { oczyszczanie, lifting }\end{array}$ & tak \\
\hline $\begin{array}{l}\text { Ultrafit plus UF150 } \\
\text { Peeling kawitacyjny } \\
\text { (Biomak) }\end{array}$ & $\begin{array}{l}\text { szpatuła kawitacyjna } \\
21 \mathrm{kHz}, 36 \mathrm{kHz}, 1 \mathrm{MHz} \\
4 \text { okrągłe głowice śr. } 4 \mathrm{~cm}, 6 \mathrm{~cm}\end{array}$ & $\begin{array}{c}0,5 \mathrm{~W} / \mathrm{cm}^{2} \\
5 \mathrm{~W} \text { - całkowita moc }\end{array}$ & $\begin{array}{l}\text { peeling kawitacyjny, sonoforeza, } \\
\text { kawitacja ultradźwiękowa }\end{array}$ & tak \\
\hline $\begin{array}{l}\text { Aparat do sonnoforezy NV-802X } \\
\text { (Newface) }\end{array}$ & $\begin{array}{l}3 \text { okrągłe głowice do twarzy wokół } \\
\text { oczu i do ciała }\end{array}$ & $800-3000 \mathrm{kHz}$ & sonoforeza & - \\
\hline
\end{tabular}

TABELA 4. Wybrane urządzenia do zabiegów kawitacji ultradźwiękowej [18]

\begin{tabular}{|c|c|c|c|c|}
\hline $\begin{array}{c}\text { Rodzaj urządzenia } \\
\text { producent/autoryzowany przedstawiciel }\end{array}$ & $\begin{array}{l}\text { Rozmiar głowicy }\left(\mathrm{cm}^{2}\right) \\
\text { i częstotliwość }(\mathrm{kHz})\end{array}$ & $\begin{array}{l}\text { Maksymalne } \\
\text { natężenie } \\
\left(\mathrm{W} / \mathrm{cm}^{2}\right)\end{array}$ & Tryb pracy & CE \\
\hline $\begin{array}{l}\text { Gemini V } \\
\text { Instytut Lesthezone }\end{array}$ & $\begin{array}{l}78 \\
40\end{array}$ & 60 & ciągły, impulsowy, regulacja & tak \\
\hline $\begin{array}{l}\text { Urządzenie wielofunkcyjne } \\
\text { Lipokawitacja + RF bipolarna } \\
\text { Image }\end{array}$ & $\begin{array}{c}18,09 \\
35\end{array}$ & 6 & impulsowy & tak \\
\hline $\begin{array}{l}\text { Kawitacja ultradźwiękowa } \\
\text { i drenaż magneto-kinetyczny } \\
\text { Pryzmat }\end{array}$ & $\begin{array}{c}\text { emitery stacjonarne } \\
4 \text { szt. } \times 300 \\
18-40\end{array}$ & 3 & impulsowy & tak \\
\hline $\begin{array}{l}\text { Duotechnology } \\
\text { (ultradźwięki + RF } 9 \text { głowic) } \\
\text { Coccon }\end{array}$ & $\begin{array}{c}\text { płaska } 50 \mathrm{~mm} \\
\text { wklęsła } 50 \mathrm{~mm} \\
36-40\end{array}$ & 120 & ciągły, impulsowy & tak \\
\hline $\begin{array}{l}\text { Slimcav plus } \\
\text { Metrum Cryoflex }\end{array}$ & $\begin{array}{c}12 \\
28-40\end{array}$ & 40 & $\begin{array}{l}\text { ciągły, impulsowy, adaptacyjny, } \\
\text { zmnienny }\end{array}$ & tak \\
\hline $\begin{array}{l}\text { Cavix } \\
\text { Ecleris }\end{array}$ & $\begin{array}{c}12 \\
36-44\end{array}$ & 3 & ciągły, impulsowy & \\
\hline
\end{tabular}


6. Plaskiewicz A, Kałużny K, Kochański B, Ploszaj O, Lulińska-Kuklik E, Weber-Rajek M, et al. Zastosowanie fizykoterapii w leczeniu dolegliwości bólowych odcinka lędźwiowego kręgosłupa. J Educ Health Sport 2015;5(5):11-20. http://ojs.ukw.edu.pl/index.php/johs/article/view/2015\%3B5\%285\%29\%3A11-20 (6.01.2017).

7. Wróblewska I, Maj J, Chilicka-Jasionowska K. Aparatura kosmetyczna i metodyka zabiegów. Opole: Państwowa Medyczna Wyższa Szkoła Zawodowa w Opolu; 2013

8. Kamm A. Sezonowe menu zabiegowe. Beauty Forum 2016;11:34-47.

9. Marwicka J, Niemyska K, Cieślicka O. Celllulit. Przegląd zabiegów kosmetycznych. Kosmetol Estet 2015;3:287-94.

10. Kasprzak W, Mańkowska A. Fizjoterapia w kosmetologii i medycynie estetycznej. Warszawa: PZWL; 2001.

11. Płaszewski M. Terapia ultradźwiękowa. Rehabilitacja. Medycyna praktyczna dla pacjentów 2015. https://rehabilitacja.mp.pl/fizykoterapia/ leczenie-ultradzwiekami/129575,terapia-ultradzwiekowa (6.01.2017).

12. Straburzyńska-Lupa A, Kornacka A. Zastosowanie ultradźwięków w leczeniu tzw. „ostrogi piętowej” w świetle badań własnych. Ortop Traumatol Rehabil 2005;7(1):79-86. http://www.ortopedia.com.pl/abstracted. php?level=5\&ICID=443079 (6.01.2017).
13. Szwedo J. Niektóre sposoby zastosowania ultradźwięków. CX News 2010;3(33). http://www.cxnews.pl/niektore-sposoby-zastosowania-ultradzwiekow,283.html (6.01.2017).

14. Magdziarz-Orlicz J. Forum praktyków - ultradźwięki w dermatologii estetycznej i kosmetyce. Dermatol Estet 2007;6(53). http://www. aktiv-press.2a.pl/en/7/dermatologia_estetyczna_archiwum_chronologiczne/0/395/forumpraktykoacutewnbspndashultradzwiekiw_dermatologii_estetycznej_i_kosmetyce/ (6.01.2017).

15. Goik U, Goik T, Załęska-Żyłka J. Zastosowanie ultradźwięków w kosmetyce i kosmetologii. Pol J Cosmetol 2012;3:170-6.

16. Kurek-Górecka A, Rakoczy B. Metody zwiększania transportu przeznaskórkowego substancji biologicznie aktywnych zawartych w kosmeceutykach. Dermatol Estet 2013;5-6:324-7.

17. Bandachowicz D. Zastosowanie ultradźwięków w redukcji tkanki tłuszczowej. Pol J Cosmetol 2013;3;186.

18. Kępa A. Kawitacja ultradźwiękowa - skuteczna metoda w redukcji nadmiaru tkanki tłuszczowej. Polska Kosmetologia i Kosmetyka. http:// www.pkik24.pl/warto-wiedziec/kawitacja-ultradzwiekowa-skutecznametoda-redukcji-nadmiaru-tkanki-tluszczowej (6.01.2017)

19. Kępa A. Medycyna estetyczna „wczoraj” i dziś. Kosmetol Estet 2012;2:119-22. 